Public Abstract

First Name:Syed

Middle Name:

Last Name:Barizuddin

Adviser's First Name:Shubhra

Adviser's Last Name:Gangopadhyay

Co-Adviser's First Name:Kevin

Co-Adviser's Last Name:Gillis

Graduation Term:SP 2010

Department:Electrical Engineering

Degree:PhD

\title{
Title:SELF-ALIGNED MICROCHIP DEVICE FOR AUTOMATED MEASUREMENT OF QUANTAL EXOCYTOSIS
}

The nature of the cells is such that they adhere well to some surfaces and not as well to others. This premise is of the utmost importance in fabricating these devices, and our work involves modifying substrate surface with lithographic techniques to meet this end. This adherence property of cells with respect to materials, when used with the process of microfabrication can be used to target, sort or study many single cells in parallel. Here we describe a protocol to fabricate a multi channel high throughput microchip device for measurement of hormone and neurotransmitter secretions from individual cells. These measurements are usually carried out using probes, which are manually manipulated to the cellâ€ ${ }^{\mathrm{TM}} \mathrm{S}$ surface while observing under the microscope. These approaches are extremely time consuming, labor intensive and require sophisticated equipment. We have developed a microchip device platform that performs single-cell assays of hormonal/neurotransmitter secretion through self-aligning of cells on electrochemical microelectrodes. The device is fabricated in such a way that single cell sized docking sites on the biocomptible and cell friendly electrochemical electrodes are exposed to the surface such that single cells can adhere to them, whereas all other areas are covered with a thin film, with properties that inhibit cell adhesion. This thin film also provides electrical isolation between the microelectrodes. We believe that development of this approach will provide much more efficiencient and faster means than the current technologies used today for similar applications.

Key words: automatic cell positioning, quantal exocytosis, amperometric detection. 